\title{
NUMERICAL ANALYSIS OF ADDITIVELY MANUFACTURED, INDIVIDUAL TITANIUM IMPLANTS DESIGNED IN A VIRTUAL ENVIRONMENT
}

\author{
Klaudia KULCSÁR, ${ }^{1}$ János KÓNYA ${ }^{2}$ \\ ${ }^{1}$ Dent-Art-Technik Kft. Györ, Hungary, kulcsar.klaudia@dentarttechnik.hu \\ ${ }^{2}$ Dent-Art-Technik Kft. Györ, Hungary, labor@dentarttechnik.hu
}

\begin{abstract}
The aim of this study is the design, manufacture, and development of a metallic rehabilitation device (titanium frame structure) that is created with a printing process. Product design is inspired by the Computed Tomography (CT) based reconstruction method, during which a metallic frame structure is designed that perfectly fits the retrieved bone surface. The internal structure of the designed metallic frames is a statically analysed three-dimensional construct which makes it possible to create individual product types. Constructs with different structure are checked by finite element analysis. Our goal is to establish a standardised manufacturing process, in which specific mechanical stressing can be carried out and optimal product type chosen, depending on different cases. At the end of this study, our solution of choice is demonstrated with surgical pictures.
\end{abstract}

Keywords: additive manufacturing, virtual design, implant, subperiosteal implant, numerical analysis.

\section{Introduction}

In recent years, treatment of edentulous jawbones with dental implants has become a completely routine procedure. The use of dental implants can yield a true advantage for edentulous patients who have difficulties with conventional prostheses [1]. Walton et al. compared patient satisfaction regarding jawbone overdentures that were retained by one or two implants. 86 patients were included in this randomized clinical study with a follow-up time of one year. Researchers reported lower costs and reduced treatment times together with similar patient satisfaction and similar times for treatment compared to single midline implants [2]. However, some studies reported unexpectedly high failure rates for single implants after immediate loading [3]. Other researchers concluded that overdentures should be supported by 3 or 4 implants. Theoretically, the use of 3 or 4 implants results in a stiffer connection instead of a straight-line connection. Three-implant-supported prosthesis is the most beneficial, implants provide indirect retention for the denture. Thus, some authors recommend the use of three or four implants in those cases where increased retention or higher alveolar ridge is required [4]. Meijer et al. did not find any relevant difference in clinical and radiological outcomes of two-implant-supported and four-implant-supported mandible overdentures during a ten-year follow-up time [5]. Together with retention, it is also important that implants are not subjected to excessive loading. With natural teeth, the periodontal ligament serves as an interstitial soft layer during occlusal loading [6]. With endosseous dental implants, occlusal loading appears directly in the neighbouring bone tissue. In the case of overload, extensive deformation occurs in adjacent bone tissue. If pathological overload occurs, stress and strain gradients exceed the physiological limits of bone tissue. Micro cracks can appear on the bone-implant interface, which can lead to implant fracture, loosening of the implant system components, or unwanted bone resorption [7, 8]. Recognizing the damage due to excessive loading, specific attention is paid 
to stress and strain levels in implant-neighbouring bone tissue. Three-dimensional finite element analysis can be considered a precise and sufficient approximation in the investigation of stress and strain distribution. It has numerous advantages in the simulation of the complexity of clinical situations [9].

Bone tissue peri-implantitis emerges in almost $56 \%$ of patients with implant-supported dentures, which leads to permanent tooth loss at the end [10]. Most of the many causes of peri-implantitis are clinically uncontrollable [11]. Maxillary bone loss combined with implant loss, or atrophy due to unsuitability present a great challenge. Current solutions include "all-on-4" implants if sufficient bone volume is present. "Quad zygoma" or in other words zygoma implants, and osteoplasty followed by (repeated) implantation is also a possible solution [12, 13].

The development of the CADCAM system provides precise pre-operation planning and personalized implant design [14, 15]. The design process of personalized implants is the following: conversion of 2D CT images to 3D DICOM files; individual implant design with a 3D software; printing the 3D stereolithography (STL) specimen; three-dimensional titanium implant production with a 3D-printer [16].

Additive manufacturing (AM), which is generally called 3D printing, is a group of such processes that create parts from three-dimensional (3D) model data, and the build-up of objects is carried out layer-by-layer [17]. ]. In recent years, several studies have appeared focusing on the use of AM technique in tissue surgery [18-21]. Tissues for bone and heart were successfully created [22]. According to ASTM F2792-12a standard, both selective laser melting (SLM) and electron beam melting (EBM) are classified as powder-bed fusion technologies, where thermal energy melts certain regions of the powder bed [17].

Titanium and its alloys are widely used as metallic implant materials for dental and orthopedic applications due to their good osseointegration properties [23-25]. Pure titanium and titanium aluminium vanadium (Ti6Al4V) possess a naturally occurrent passive superficial oxide layer, which provides biological benefits and corrosion resistance, while the bulk material has good mechanical properties and high strength/mass ratio [26]. It was found that implant surface roughness is such a factor that can promote osseointegration process in vivo [27, 28]. Although, success rates of dental implants are more than $95 \%$ in heathy patients (people under treatment), certain risk factors still prevent osseointegration. Diabetes and smoking dramatically reduce osseointegration rate [29].

The behaviour of endosseous implants can be investigated with numerical methods. In recent years, finite element method [30] has been used to forecast stress and strain distribution near the implant, to investigate the effects of implant and prosthesis [31-34], to calculate load magnitude and direction, [35, 36] and to model mechanical properties of bone [37, 38], and different clinical scenarios [39, 40].

Implant endurance is influenced by the biological reactions of bone tissue to mechanical load [41]. As mechanical stresses appear in the bone tissue through the implant and prosthesis, denture design and production must be carried out carefully. One of the major aspects of this is the achievement of adequate stress distribution in bone tissue [42]. In recent times, mainly two-dimensional (2D) and three-dimensional (3D) finite element analyses (FEA) have been used to investigate bone tissue correlation in implant-supported overdentures. Comparative studies have demonstrated the accuracy of these analyses. Although, if detailed information is needed about stresses, 3D modelling is necessary [43].

The most frequent cause of implant failure is poor oral hygiene and biomechanical factors [44]. A]. Implants must withstand stresses caused by intermolar forces. Increased or abnormal load, together with fatigue caused by physiological load can lead to fracture of the components of the implant system [45].

Finite element (FE) analysis is widely used to evaluate stresses in implant-surrounding bone tissue of edentulous jawbones [46]. Meijer et al. used a three-dimensional FE model that represented internal forces exerted by the jawbone [47].

Finite element method (FEM) contains several computational procedures to calculate stress and strain distribution. With a structural analysis of this kind, we can determine stress and strain levels caused by external forces, pressure, temperature change, or other factors [48].

\section{Materials and methods}

\subsection{Properties of the chosen titanium alloy}

Titanium and its alloys have outstanding corrosion resistance and biocompatibility. The most widely-used titanium alloy for prostheses, implants, and medical devices is Ti-6Al- $4 \mathrm{~V}$, which is 
the standard material of choice for osteoplasty. The material of specimens to be manufactured with LMF (laser metal fusion) technology is Grade23 Ti-6Al-4V alloy. The manufacturer of the metal powder is LPW Technology Ltd. (Runcom, United Kingdom). Average particle size of the material is typically between $10-45 \mu \mathrm{m}$. To avoid oxidation, packaging and storing of the powder material takes place in argon atmosphere. Material composition in mass percentage is shown by Table 1.

Apart from the most important reasons, titanium is the ninth most occurrent element, making up $0.63 \%$ of the earth, with low specific weight and anti-allergenic effects. In implantology, the surface oxide layer is responsible for bone tissue connection. Thanks to its low specific weight titanium significantly reduces the total mass of implants and increases patient comfort. Moreover, used as a metallic frame structure, it does not cause any tinge taste in the oral cavity. Allergic reactions re-ported in the literature are even less frequent than that for gold material.

\subsection{Additive technology}

3D printing is an additive manufacturing technology that applies/lays on thin layers of material to create parts. Three-dimensional objects can be built up with 3D printing using digital models. Additive manufacturing is preceded by digital modelling (STL) (triangular surface structure). Our 3D printer works with own LMF technology, which is used for the manufacturing of complex metallic parts from powder material. LMF process is capable of producing complex internal structures. La-

Table 1. Chemical composition of Ti-6Al-4V in mass percentage

\begin{tabular}{|c|c|c|c|}
\hline \multirow{4}{*}{ Alloy } & \multicolumn{3}{|c|}{ Chemical composition $\mathbf{~} / \mathbf{m} \%$} \\
\cline { 2 - 4 } & Element & $\mathbf{m i n}$ & $\mathbf{m a x}$ \\
\hline \multirow{7}{*}{$\begin{array}{c}\text { LPW Ti64 } \\
\text { Grade 23 }\end{array}$} & $\mathrm{Al}$ & 5.5 & 6.5 \\
\cline { 2 - 4 } & $\mathrm{C}$ & & 0.08 \\
\cline { 2 - 4 } & $\mathrm{Fe}$ & & 0.25 \\
\cline { 2 - 4 } & $\mathrm{H}$ & & 0.0125 \\
\cline { 2 - 4 } & $\mathrm{N}$ & & 0.03 \\
\cline { 2 - 4 } & $\begin{array}{c}\text { other sep- } \\
\text { arate }\end{array}$ & & 0.13 \\
\cline { 2 - 4 } & other sum & & 0.1 \\
\cline { 2 - 4 } & $\mathrm{Ti}$ & rest & 0.4 \\
\cline { 2 - 4 } & $\mathrm{V}$ & 3.5 & rest \\
\hline
\end{tabular}

ser melts the metal powder and builds up the object layer-by-layer to achieve its desired contour. Ideal scanning path of solid-state lasers is defined by an intelligent software. Printing of specimens and models was carried out with a SISMA Mysint 100 3D printer using laser beam melting. The printer can be seen in operation in Figure 1.

3D-printed specimens and models are removed from the building platform after the additive manufacturing process. Figure 2. presents specimens as they leave the 3D-printer.

The 3D printing process can be separated into three main steps:

- preparation;

- 3D printing;

- post-processing

\section{Individual titanium implant}

With the realization of the individual implant, titanium frame, we provide such a solution in rehabilitation that can even improve patients' life conditions. The volume of tissue to be removed can be so excessive in patients suffering from tumour or other bone defects that skull bone will be unable to provide sufficient support for soft tissues. Metal frame structures can be used for such extensive bridging. Unlike conventional

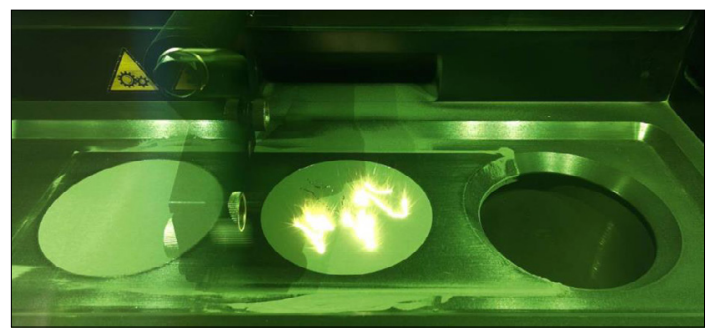

Figure 1. SISMA Mysint printer in operation

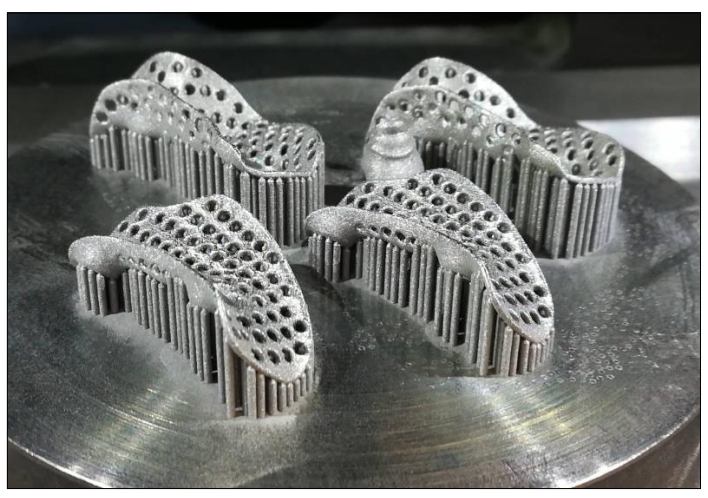

Figure 2.3D-printed specimens 
solutions, we prefer using a special metal frame structure.

Product design is performed by using a CT-based reconstruction method, where the aim is to create a metal frame precisely fitting the extracted, real bone surface. Not only is the geometry of the metal frame designed, but the internal structure of the material is as well. Internal structure of the thus created metal frames is sized statically and dynamically. This three-dimensional structure enables the production of individual product types.

The first process step in our developed technique is virtual design. In this phase, we can create the precise, three-dimensional image of the affected bone surface thanks to computerized imaging and image processing software. The first design phase is CT processing, then bone surface generation takes place, as visible step-by-step in Figure 3.

An STL file is generated from the CT image, then error repair of this STL file is performed. It is then followed by the correction of the ideal denture. Figure 4. shows the process for the determination of fixation/breakthrough points based on ideal denture design.

It is followed by metal frame design, which is still carried out in a virtual environment. The first step of this process is the definition of borderline for the titanium frame considering the previously optimized denture. Afterwards, parameters for this frame (thickness, geometric structure) are defined. These steps are visualized in Figure 5.

Both the bone surface and the implant are available to be built with 3D printing technology if necessary. It provides direct visualization and draws attention in time to possible difficulties at surgery. Figure 6. shows this step.

Afterwards, surgical insertion of the titanium frame can be carried out with screw fixation that is consistent with the previously created holes at the computer-aided design process.
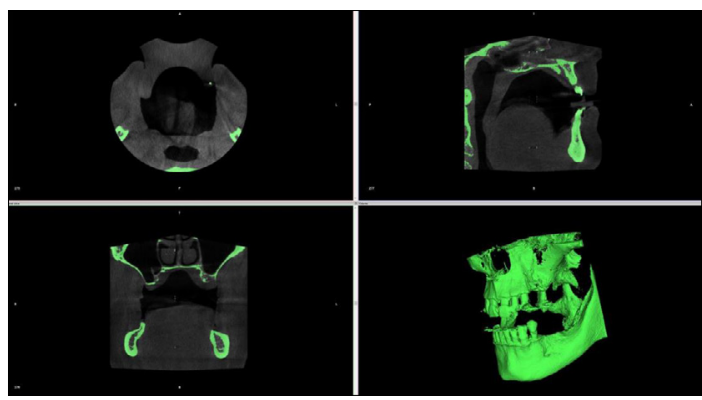

Figure 3. CT processing and bone surface generation

\section{Numerical analysis of individual implant}

The subperiosteal implant, or in other words cortically-supported individual implant, as we call it today, was first developed in 1936. In those days, implant material was Vitallium and a certain type of carbon steel. [2,8] Dent-Art-Technik Kft. (Győr, Hungary) developed a titanium subperiosteal implant, for which the Magyar Nagydíj Prize was awarded in 2014.

Different geometrical structures are evaluated in this study. Implant geometries can vary differently, several solutions can be found in the scientific literature. This study mainly focuses on three-dimensional implant structure and closed or open implant edges. The following figure shows the main geometrical structures.

Table 2. presents the extent of structuredness, degree for closed or open cells, and thickness. Evidently, more examinations were carried out, but those results were not relevant. In the following table, titanium structures are presented according to Figure 7. Rows in the table show each of the frame structures respectively as seen in Figure 7. In the first row, there is the closed-edge plate with a thickness of $0.65 \mathrm{~mm}$ and internal structures of $1.5 \mathrm{~mm}$. The second row shows a $0.65 \mathrm{~mm}$ thick plate with non-closed edges and $1.5 \mathrm{~mm}$ inter-

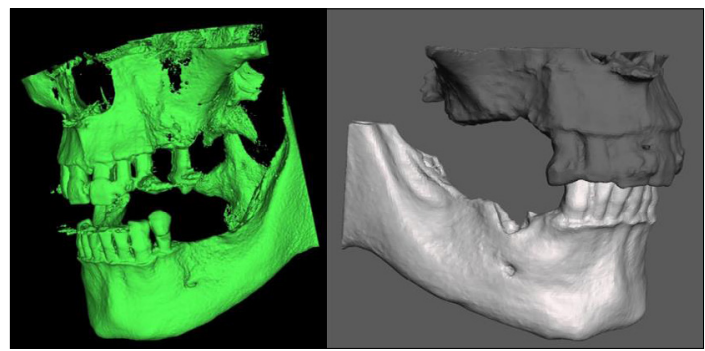

Figure 4. STL file generation and design of an ideal denture

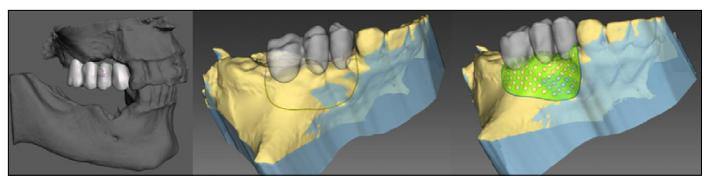

Figure 5. Determination of borderline and parameters of titanium frame

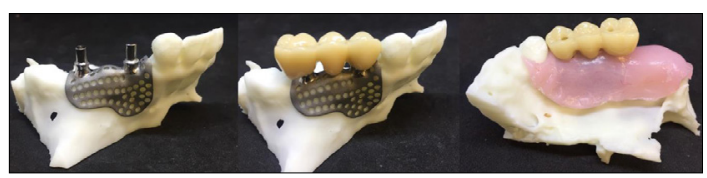

Figure 6. Visualization created with $3 D$ printing 
Table 2. Data and results for tested titanium frames

\begin{tabular}{|l|c|c|}
\hline Titanium frame & Stress [Mpa] & Strein [mm] \\
\hline $\begin{array}{l}\text { Closed edge, } 1,5 \\
\text { mm structured }\end{array}$ & 34.683 & 0.0043 \\
\hline $\begin{array}{l}\text { Non-closed edge, } \\
1,5 \mathrm{~mm} \text { structured }\end{array}$ & 61.105 & 0.0427 \\
\hline $\begin{array}{l}\text { Closed edge, } 1 \mathrm{~mm} \\
\text { structured }\end{array}$ & 183.122 & 0.1243 \\
\hline
\end{tabular}

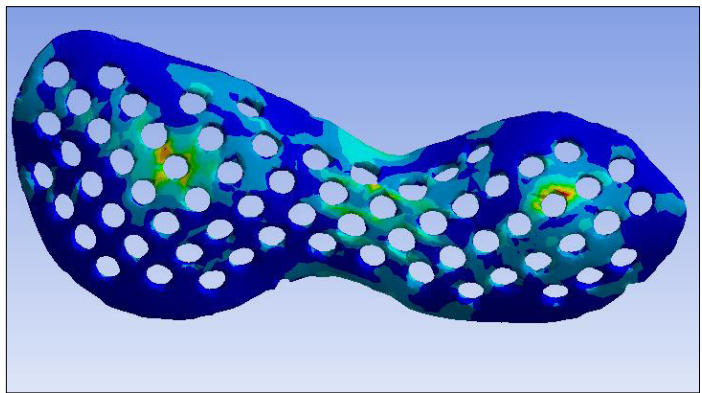

Figure 9. Stress levels in the titanium frame

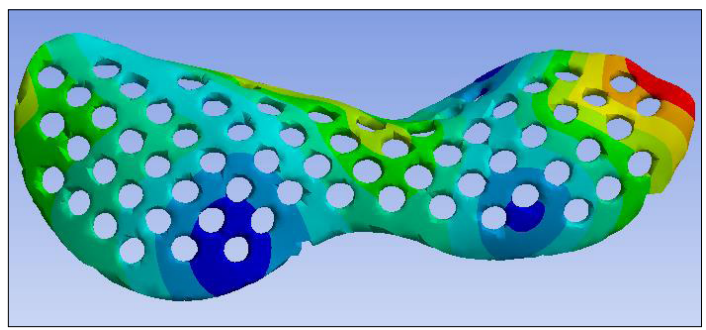

Figure 10. Strain levels in the titanium frame

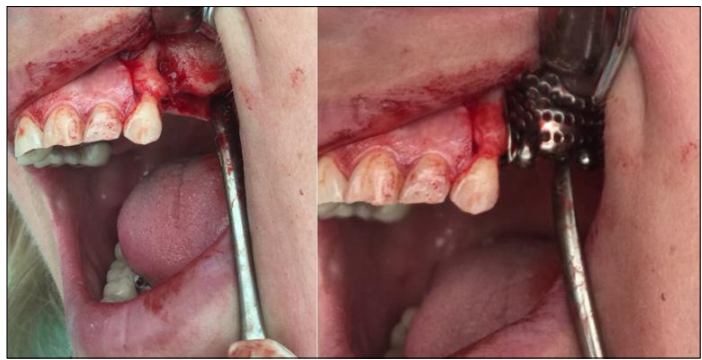

Figure 11. Titanium frame insertion to the patient

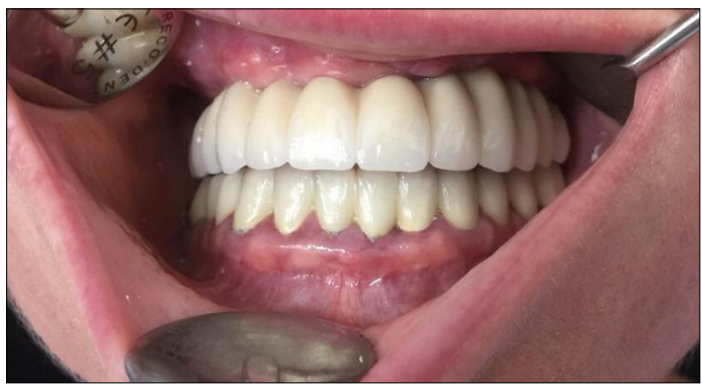

Figure 12. Fixed final denture

Such strain levels are calculated due to the occlusal force with an inclined angle of action. The extent of deformation is minimal.

Surgery was performed following the production of the individual implant. Surgical pictures are shown in Figure 11, which were taken by Dr. Géza Friedreich, who performed a successful operation in Budapest.

Figure 12. presents the fixed, virtually designed final denture anchored on individual implants in the patient's oral cavity. 


\section{Summary}

According to our presented technique, it becomes possible to create a denture that is aesthetically and functionally similar to that of own natural dentition without the necessity of replacing hard tissues and long, risky series of operations.

\section{Acknowledgement}

We would like to thank oral surgeon and dentist Dr. Géza Friedreich for performing the operation. We are also grateful to dental technician, CAD -and individual implant designer, Lajos Bozsányi at Dent-ArtTechnik Kft.

„EFOP-3.6.1-16-2016-00017 Internationalization, initiatives to establish a new source of researchers and graduates, and development of knowledge and technological transfer as instruments of intelligent specializations at Szechenyi University”.

\section{References}

[1] Bergendal T., Engquist B.: Implant-supported overdentures: a longitudinal prospective study. International Journal of Oral and Maxillofacial Implants 13/2. (1998) 253-262.

https://pdfs.semanticscholar.org/51c6/9f4cf669b6d23c30e2f92bca4b81e557e746.pdf

[2] Jingyin L., Shaoxia P., Jing D., Zhongjun M., Yobu F.: Influence of implant number on the biomechanical behvaiour of mandibular implant-retained/ supported overdentures: A three-dimensional finite element analysis. Journal of Dentistry 41/3. (2013) 241-249.

https://doi.org/10.1016/j.jdent.2012.11.008

[3] Lidellow G., Henry P.: The immediately loaded single implant-retained mandibular overdenture: a 36-month prospective study. International Journal of prosthodontics 23/1. (2010) 13-21.

https://pdfs.semanticscholar.org/cb1a/ a1dbff62741d3b98e214adc474d44e3f4494.pdf

[4] Mericske-Stren R. D., Taylor T. D., Belser U.: $M a-$ nagement of the edentulous patient. Clinical Oral Implants Research 11. (2000) 108-125.

http://clinicaljude-5thyear.yolasite.com/resources/Management $\% 20$ of $\% 20$ the $\% 20$ edentulous\%20patient\%20Ref1.pdf

[5] Meijer H. J., Raghoebar G. M., Batenburg R. H., Visser A., Vissink A.: Mandibular overdentures supported by two or four endosseous implants: $a$ 10-year clinical trial. Clinical Oral Implants Research, 20/7 (2009) 722-728.

https://doi.org/10.1111/j.1600-0501.2009.01710.x

[6] Weinberger L. A.: The biomechanics of force distribution in implant-supported prostheses. International Journal of Oral and Maxillofacial Implants 17/5 (1993) 19-31.
[7] Gotfredsen K., Berglundh T., Lindhe J.: Bone reactions adjacent to titanium implants subjected to static load of different duration. Clinical Oral Implants Research, 12/6 (2001) 552-558.

https://doi.org/10.1034/j.1600-0501.2001.120602.x

[8] Frost H. M.: Bone „mass” and the „mechanostat”: a prosposal. Anatomical Record 219/1. (1987) 1-9. https://doi.org/10.1002/ar.1092190104

[9] Tepper G., Haas R., Zechner W., Krach W., Watzek G.: Three-dimensional finite element analysis os implant stability in the atrophic posterior maxilla: a mathematical study of the sinus floor augmentation. Clinical Oral Implants Research 13/6. (2002) 657-665.

https://doi.org/10.1034/j.1600-0501.2002.130613.x

[10] Lindhae J., Meyle J., on behalf of Group D of the European Workshop on Periodontology: Peri-implant disease: Consensus Report of the Sixth Europen Workshop on Periodontology. Journal of Clinical Periodontology 35/8. (2008) 282-285.

https://doi.org/10.1111/j.1600-051X.2008.01283.x

[11] Renvert S., Quirynen M.: Risk indicators for peri-implantitis. A narrative rewiev. Clinical Oral Implants Research 26/11. (2015) 15-44.

https://doi.org/10.1111/clr.12636

[12] Malevez C., Abarca M., Durdu F., Daelemans P.: Clinical outcome of 103 consecutive zygomatic implants: a 6-48 months follow-up study. Clinical Oral implants Research 15/1. (2004) 18-22. https://doi.org/10.1046/j.1600-0501.2003.00985.x

[13] Neyt L., De Clercq C. A., Abeloos J. V. Mommaerts M. Y.: Reconstruction of the severely resorbed maxilla with a combination of sinus augmentation, onlay bone grafting, and implants. Journal of Oral and Maxillofacial Surgery 55/1. (1997) 1397-1401.

https://doi.org/10.1016/S0278-2391(97)90636-4

[14] Leiser Y., Shilo D., Wolff A., Rachmiel A.: Functional recontsruction in mandibular avulsion injuries. The Journal Craniofacial Surgery, 27/8. (2016) 2113-2116.

[15] Li B., Zhang L., Sun H., Yuan J., Shen S. G. F., Wang $\mathrm{X} .:$ A novel method of computer aided orthognathic surgery using individual CAD/CAM templates: a combination of osteotomy and repositioning quides. British Journal of Oral Maxillofac Surgery 51/8. (2013) 239-244.

https://doi.org/10.1016/j.bjoms.2013.03.007

[16] Rachmiel A., Shilo D., Blanc O., Emodi O.: Reconstruction of complex mandibular defects using integrated dental custom-made titanium implants. British Journal of Oral and Maxillofacial Surgery 55/4. (2017) 425-427.

https://doi.org/10.1016/j.bjoms.2017.01.006

[17] Sing S. L., An J., Yeong W. Y., Wiria F. E.: Laser and Electron-Beam Powder-Bed Additive Manufacturting of Metallic Implants: A review on process, materials and design. Journal of Orthopeadic Research 34/3. (2015) 369-385. 
https://doi.org/10.1002/jor.23075

[18] Sudarmadji N., Tan J. Y., Leong K. F., Chua C. K., Loh Y. T.: Investigation of the mechanical properties and porosity relationship in selective laser-sintered polyhedral for functionally graded scaffolds. Acta Biomaterialia 7/2. (2011) 530-537. https://doi.org/10.1016/j.actbio.2010.09.024

[19] Yeong W. Y., Sudarmajdi N., Yu H. Y., Leong K. F., Venkatraman S. S., Boey Y. C. F., Tan L. P.: Porous polycaprolactone scaffold for cardiac tissue engineering fabricated by selective laser sintering. Acta Biomaterialia 6/6. (2009) 2028-2034. https://doi.org/10.1016/j.actbio.2009.12.033

[20] Wiria F. E., Leong K. F, Chua C. K, Liu Y.: Poly-e-caprolactone/hydroxyapatite for tissue engineeringscaffold fabrication via selective laser sintering. Acta Biomaterialia 3/1. (2007) 1-12. https://doi.org/10.1016/j.actbio.2006.07.008

[21] Yang S. F., Leong K. F., Du Z. H., Chua C. K.: The desing of scaffolds for use in tissue engineering. Part II. Rapid prototyping techniques. Tissue Engineering 8/1. (2002) 1-11.

https://doi.org/10.1089/107632702753503009

[22] Yeong W. Y., Chua C. K., Leong K. F., Chandrasekaran M.: Rapid prototyping in tissue engineering: challenges and potential. Trends in Biotechnology 22/12. (2004) 643-652.

https://doi.org/10.1016/j.tibtech.2004.10.004

[23] Van Noort R.: Titanium: the implant material of today. Journal of Materials Science 22/11. (1987) 3801-3811.

https://doi.org/10.1007/BF01133326

[24] Rack H. J., Quazi J. I.: Titanium alloys for biomedical applications. Materials Science and Engineering 26/8. (2006) 1269-1277.

https://doi.org/10.1016/j.msec.2005.08.032

[25] Long M.; Rack H. J.: Titanium alloys in total joint replecamnet - a materials science prespective. Biomaterials 19/18. (1998) 1621-1639. https://doi.org/10.1016/S0142-9612(97)00146-4

[26] Cheng A., Humayun A., Cohen D. J., Boyan B. D., Schwartz Z.: Additively manufactured $3 D$ porous Ti-6Al-4V constructs mimic trabecular bone structure and regulate osteoblast proliferation, differentiation and local factor production in a porosity and surface roughness dependent manner. Biofabrication 6/4. (2014) 1-12. https://doi.org/10.1088/1758-5082/6/4/045007

[27] Zhao G., Zinger O., Schwartz U., Wieland M., Landolt D., Boyan B. D.: Osteobalst-like cells are sensitive to submicron-scale surface structure. Clinical Oral implant Research 17/3. (2006) 258-264. https://doi.org/10.1111/j.1600-0501.2005.01195.x

[28] Zinger O., Zhao G., Schwartz Z., Simpson J., Landolt D., Boyan B.: Differential regulation of osteoblasts by substrate microstructural features. Biomaterials, 26/14 (2005) 1837-2847.

https://doi.org/10.1016/j.biomaterials.2004.06.035
[29] Bain C. A., Moy P. K.: The association between the failure of dental implants and cigarette smoking. International Journal of Oral and Maxillofacial Implants 8/6. (1993) 609-615.

http://dx.doi.org/10.1097/00008505-199409000-00011

[30] Geng J. P., Tan K. B., Liu G. R.: Application of finite element analysis in implant dentistry: a review of the literature. The journal of Prosthetic Dentistry, 85/6 (2001) 585-598.

https://doi.org/10.1067/mpr.2001.115251

[31] Rieger M. R., Adams W. K., Kinzel G. L.: A finite element survey of eleven endosseous implants. The Journal of prosthetic Dentistry 63/4. (1990) 457-465.

https://doi.org/10.1016/0022-3913(90)90238-8

[32] Chun H. J., Cheong J. H., Han J. H., Heo S. J., Chung J. P., Rhyu I. C., Choi Y. C., Baik H. K., Ki Y., Kim M. H.: Evaluation of design parameters ofosseointegrated dental implants using finite element analysis. Journal of Oral Rehabilitation, 29/6. (2002) 565-574. https://doi.org/10.1046/j.1365-2842.2002.00891.x

[33] Himmlová L., Dostálová T., Kácovsky A., Konvicková S.: Influence of implant length and diameter on stress distribution: a finite element analysis. The Journal of Prosthetic Dentistry 91/1. (2004) 20-25.

https://doi.org/10.1016/j.prosdent.2003.08.008

[34] Chun H. J., Shin H. S., Han C. G., Lee S. H.: Influence of implant abutment type on stress distribution in bone under various loading conditions using finite element analysis. International Journal of Oral and Maxillofacial Implants 21/2 (206) 195-202.

https://www.ncbi.nlm.nih.gov/pubmed/16634489

[35] Meijer H. J., Starmans F. J., Steen W. H., Bosman F.: Loading conditions of endosseous implants in an edentulous human mandible: a three-dimensional, finite-element study. Journal of Oral Rehabilitation 23/11. (1996) 757-763.

https://doi.org/10.1046/j.1365-2842.1996.d01185.x

[36] Alkan I., Sertgöz A., Ekici B.: Influence of occlusal forces on stress distribution in preloaded dental implant screws. The Journal of Prosthetic Dentistry 91/4. (2004) 319-325.

https://doi.org/10.1016/j.prosdent.2004.01.016

[37] Kitagawa T., Tanimoto Y., Nemoto K., Aida M.: Influence of cortical bone quality on stress distribution in bone around dental implant. Dental Materials Journal 24/2. (2005) 219-224.

http://dx.doi.org/10.4012/dmj.24.219

[38] Lin C. L., Kuo Y. C., Lin T. S.: Effects of dental implant length and bone quality on biomechanical responses in bone around implants: a 3D non-linear finite element analysis. Biomedical Engineering: Applications, Basis and Communications, 17/1. (2005) 44-49.

https://doi.org/10.4015/S1016237205000081 
[39] Saab X. E., Griggs J. A., Powers J. M., Engelmeier R. L.: Effect of abutment angulation on the strain on the bone around an implant in the anterior maxilla: a finite element study. The Journal of prosthetic Dentistry 97/2. (2007) 85-92. https://doi.org/10.1016/j.prosdent.2006.12.002

[40] Natali An. N., Pavan P. G., Ruggero A. L.: Evaluation of stress induced in peri-implant bone tissue by misfit in multi-implant prosthesis. Dental Materials 22/4. (2006) 388-395. https://doi.org/10.1016/j.dental.2005.08.001

[41] Bidez M. W., Misch C. E.: Issues in bone mechanics related to oral implants. Implant Dentistry 1/4. (1992) 15-44. https://doi.org/10.1097/00008505-199200140-00011

[42] Stegaroiu R., Takahiro S., Haruka K., Osamu M.: Influence of restoration type on stress distribution in bone around implants: a three-dimensional finite element analysis. International Journal of Oral \& Maxillofacial 13/1. (1998) 82-90.

[43] Simon B. R., Woo S. L. Y., Olmstead S. R., McCarty M. P., Jemmott G. F., Akeson W. H.: Evaluation of one-, two-, and three-dimensional finite element and experimental models of internal fixation plates. Journal of Biomechanics 20/2. (1977) 79-86. https://doi.org/10.1016/0021-9290(77)90071-9

[44] Quirynen M., Naert I., Van Steenberghe D.: Fixture design and overload influence marginal bone loss and fixture success in the Brånemark system.
Clinical Oral Implants Research 3/3. (1992) 104111.

https://doi.org/10.1034/j.1600-0501.1992.030302.x

[45] Adell R., Lekholm U., Rockler B., Bränemark P. I.: A 15-year study of osseointegrated implants in the treatment of the edentulous jaw. International Journal of Oral Surgery 10/6. (1981) 387-416. https://doi.org/10.1016/S0300-9785(81)80077-4

[46] Meijer H. J. A., Kuiper J. H., Starmans F. J. M, Bosman F.: Stress distribution around dental implants: Influence of superstructure, length of implants and height of mandible. The Hournal of Prosthetic Dentistry, 68/1. (1992) 96-102. https://doi.org/10.1016/0022-3913(92)90293-J

[47] Meijer H. J. A., Starmans F. J. M., Steen W. H. A., Bosman F.: Location of implants in the interforaminal region of the mandible and the consequences for the design of the superstructure. Journal of Oral Rehabilitation 21/1. (1994) 47-56.

https://doi.org/10.1111/j.1365-2842.1994. tb01123.x

[48] Wakabayashi N., Ona M., Suzuki T., Igarashi Y.: Nonlinear finite element analyses: Advances and challenges in dental applications. Journal of Dentistry, 36/7 (2008) 463-471.

https://doi.org/10.1016/j.jdent.2008.03.010

[49] Kónya J., Kulcsár K.: Additív technológiával készülő egyéni implantátumok lézeres mikro hegesztésének vizsgálata. Acta Materialia Transylvanica 2/1. (2019) 